\section{ANOTHER LOOK AT ASPECT IN THAI ${ }^{1}$}

\author{
Pranee Kullavanijaya ${ }^{2}$ \\ Walter Bisang ${ }^{3}$
}

\section{Abstract}

The aim of the paper is twofold. The first aim is to analyse aspect in Thai in the framework of the selection-theory approach developed by Breu and Sasse (1991). The second aim is to study all possible co-occurrences of each of the

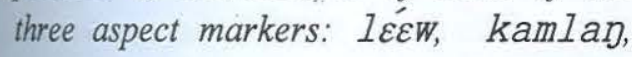
yiu with the four classes of verbs and with the verbs occurring with other strategies within the five classes of states of affairs. It was found that the selectional approach chosen helped explaining the inceptive-stative state of affairs in Thai clearly. It also pointed out that the Thai aspectuality focused on the initial boundary and terminative boundary of the state of affairs. It is here that combinations of the three aspect markers occur. The study shows that they have certain rules of co-occurances.

Keywords: aspect, selection-theory, Thai

\section{Introduction}

The aim of this paper is to describe the three aspect markers: lécw, yùu and kamlan in Thai from the selection-theory approach developed by Breu and Sasse

'This paper was presented at the SEALS XIII Conference in Bangkok in May 2004.

${ }^{2}$ Professor, Department of Linguistics, Faculty of Arts, Chulalongkorn University, Bangkok, Thailand.

${ }^{3}$ Department of Linguistics, University of Mainz, Mainz, Germany.
(Sasse, 1991). We select this approach because it allows us to explain an inceptive-stative state of affairs in Thai which an approach such as a viewpoint approach cannot. In this approach, aspect markers interact with the relevant temporal structure of verbs/states of affairs. A further aim is to study both the mutual compatibility of the three aspect markers among themselves as well as with different classes of states of affairs.

We will begin first with a brief discussion of aspect from a general perspective followed by a brief survey of previous studies of aspect in Thai. Then, we will present classes of verbs and states of affairs in Thai within the selection-theory framework. In the last part, we will give a picture of aspect in Thai, first with each of the three aspect markers mentioned above, then with the combination of these aspect markers.

\section{Aspect from a general perspective}

Aspect and its definition is a notorious problem in linguistics. Few grammatical catergories have been treated and still are treated more extensively and with more terminological and notional confusion than the one of aspect. A recent study by Sasse (2002) which provides an excellent survey of the different approaches to this phenomenon confirms this statement. In our present study, we shall look at aspect from the perspective of a selection-theory of aspect as defined by Bickel (1997). This perspective combines the two main traditions in research on aspect, that is, the viewpoint approach (Koschmieder 1928/1929, 1934, Maslov 1962, Comrie 1976) and the time-schema approach which was mainly developed in the United States (Vendler 1967, Dowty 1979). 
The viewpoint approach: This approach roughly distinguishes two types of aspect, perfective and imperfective which are inflectional and thus obligatory. This dichotomy is typically attested in languages such as Greek, Russian or Bulgarian. The viewpoint dichotomy can also be referred to as aspect proper or ASPECT $_{1}$ as defined by Sasse (1991). The main dichotomy between perfective and imperfective can be defined as follows:

The operator of imperfective aspect presents a state of affairs as a situation without any reference to its temporal boundaries. It highlights the phase.

The operator of perfective aspect presents a state of affairs as a change of state with explicit reference to its inherent temporal boundaries.

The time-schema approach: This approach is considered by Sasse (1991) as an Anglo-American answer to the continental, perfective-imperfective-based theory. In this approach inherent temporal characteristics of predicates are discussed as temporal patterns or time-schemata. Four time-schemata: states, activities, accomplishments and achievements were proposed by Vendler. These timeschemata are roughly described in terms of verb classes. Semantic temporal features such as $[ \pm$ static $],[ \pm$ punctual $]$ are used to distinguish the verbs. In Table 1 verb classes in English based on the semantic properties: $[ \pm$ static $],[ \pm$ telic $]$ and [ \pm punctual] following Vendler (1967) are given.

\begin{tabular}{|l|l|l|}
\hline State & [+static], [-telic], [-punctual] & be sick, be dead, love, know \\
\hline Activity & [-static], [-telic], [-punctual] & march, walk, swim, read \\
\hline Accomplishment & [-static], [+telic], [-punctual] & melt, freeze, learn \\
\hline Achievement & [-static], [+telic], [+punctual] & pop, explode, collapse, shatter \\
\hline $\begin{array}{l}\text { [+static]: } \\
\text { [+telic]: }\end{array}$ & suggesting non-dynamic state of affairs. \\
[+punctual]: & suggesting inherent terminal point in the state of affairs.
\end{tabular}

Table 1. English verb classes following Vendler's (1967)

A number of tests have been developed for deciding to which class a verb in a given language belongs. Table 2 from Van
Valin \& LaPolla (1997: 94) provides a nice summary: 


\begin{tabular}{|l|c|c|c|c|}
\hline \multicolumn{1}{|c|}{ Criteria } & States & $\begin{array}{c}\text { Achieve- } \\
\text { ments }\end{array}$ & $\begin{array}{c}\text { Accomplish- } \\
\text { ments }\end{array}$ & Activities \\
\hline Occurs with progressive & No & No & Yes & Yes \\
\hline $\begin{array}{l}\text { Occurs with adverbs like } \\
\text { vigorously, actively, etc. }\end{array}$ & No & No & No & Yes \\
\hline $\begin{array}{l}\text { Occurs with adverbs like } \\
\text { quickly, slowly, etc. }\end{array}$ & No & No* & Yes & Yes \\
\hline $\begin{array}{l}\text { Occurs with time adverbials } \\
\text { like for an hour. }\end{array}$ & Yes* & No & Irrelevant & Yes \\
\hline $\begin{array}{l}\text { Occurs with time adverbial: } \\
\text { in an hour }\end{array}$ & No & No* & Yes & No \\
\hline
\end{tabular}

Table 2. Criteria for verb classification (from Van Valin \& LaPolla 1997: 94)

The selection-theory approach: The combination of the viewpoint approach and the time-schema approach in selection theories is quite straightforward inasmuch as aspect markers as defined in the viewpoint approach operate on the temporal properties of states of affairs as defined in the time-schemata approach. If we take the opposition between passé simple (perfective) and imparfait (imperfective) in French and apply these two operators to a state of affairs belonging to the class of activities with the use of an activities verb rûler 'to rule', we get the following clauses:

(1) a. Perfective:

Il rûla trente ans.

'He ruled thirty years.'

b. Imperfective:

Il rûlait trente ans.

'He ruled thirty years.'

Although the English translation is the same, in the perfective case of (1a), the state of affairs of 'ruling thirty years' is seen within the initial and the terminal boundaries of thirty years. This is not the case with the imperfective in (1b), in which no attention is paid to the boundary structure of the state of affairs.

Selection theories of aspect understand aspect markers as operators that select matching temporal phases as they are determined in the temporal semantics of a state of affairs with the temporal boundaries (Bickel 1997). The basic idea of this approach is that verbs and states of affairs as a whole as they are syntactically reflected by sentences have their temporal structures. These structures consist of temporal boundaries and phases. Temporal boundaries are characterized by changes of situations; situations are stretches of time within which a given state of affairs takes place. The temporal structure of verbs is inherent in the sense that it is part of the lexicon. Some theories only look at temporal structures as they are defined in the lexicon of individual languages. Other theories also integrate entire states of affairs. In the latter case, additional temporal boundaries can be added by adverbials or other markers. In this paper, we will take this stand. Given the temporal structure of verbs or states of affairs, the function of temporal operators is to operate on these structures. How this is done and what models of temporal 
structures there are will be further clarified in the rest of this paper.

A number of selection-theory approaches are based on the four-class system as developed by Vendler (1967) and Dowty (1979). For our description of aspect in Thai in this paper, however, we need to introduce another system developed by Breu and Sasse (presented here according to Sasse (1991)); for Breu's approach and its further development, see Breu (1985, 2000.) The Breu and Sasse system distinguishes five classes. These classes are defined on the basis of the following components: the initial change of situation (CS1) or the initial temporal boundary, the situation (S) or the phase itself and the terminal change of situation (CS2) or the terminal temporal boundary.

\begin{tabular}{|l|ll|l|}
\hline Totally stative (TSTA): & CS1 & [S] CS2 & know, be dead, exist \\
\hline Inceptive-stative (ISTA): & {$[\mathrm{CS} 1 \quad$ S $\quad$ CS2 } & sit down, get to know \\
\hline Action (ACTI): & {$[\mathrm{CS} 1 \quad$ S CS2] } & work, sing, drink \\
\hline Gradually terminative (GTER): & $\mathrm{CS} 1 \quad[\mathrm{~S}$ CS2] & die, kill, melt \\
\hline Totally terminative (TTER): & $\mathrm{CS} 1 \quad \mathrm{~S}[\mathrm{CS} 2]$ & reach \\
\hline
\end{tabular}

Table 3. The Breu and Sasse five classes of states of affairs with examples of verbs in English (Sasse, 1991)

The main reason why we need this approach is because the Vendler or Dowty system does not provide a class which is characterized exclusively by an initial temporal boundary and because, at the level of entire states of affairs, Thai aspect markers also operate on that boundary. Table 4 shows the lack of a class with only an initial boundary in the Vendler or Dowty system. In the first four lines, we present the classes of the Vendler or Dowty system, in the fifth line the temporal structure of inceptive-stative states of affairs is added in the second column:

\begin{tabular}{|c|c|c|}
\hline $\begin{array}{l}\text { Vendler's states } \\
\text { of affairs }\end{array}$ & $\begin{array}{l}\text { States of affairs in this } \\
\text { paper }\end{array}$ & $\begin{array}{l}\text { States of affair configurations and } \\
\text { explanation }\end{array}$ \\
\hline States & $\begin{array}{l}\text { Totally Stative } \\
\text { (TSTA): }\end{array}$ & $\begin{array}{l}\text { [S] situation only, no reference to } \\
\text { temporal boundaries }\end{array}$ \\
\hline Activities & $\begin{array}{l}\text { Action } \\
\text { (ACTI): }\end{array}$ & $\begin{array}{l}{\left[\begin{array}{lll}\mathrm{CS}_{1} & \mathrm{~S} & \mathrm{C}_{2}\end{array}\right] \text { initial boundary - }} \\
\text { situation }- \text { terminal boundary }\end{array}$ \\
\hline Accomplishments & $\begin{array}{l}\text { Gradually Terminative } \\
\text { (GTER): }\end{array}$ & $\begin{array}{l}{\left[\mathrm{S} \mathrm{CS}_{2}\right] \text { situation plus terminal }} \\
\text { boundary }\end{array}$ \\
\hline Achievements & Totally Terminative (TTER): & $\begin{array}{l}{\left[\mathrm{CS}_{2}\right] \text { initial and terminal boundary }} \\
\text { collapse into one, no situation }\end{array}$ \\
\hline & Inceptive-stative (ISTA): & {$\left[\mathrm{CS}_{1} \mathrm{~S}\right]$ initial boundary plus situation } \\
\hline
\end{tabular}

Table 4. Five classes of states of affairs adopted in this paper 
Classes of states of affairs presented in Table 4 can minimally consist of an individual verb, or they can be in a more complex form consisting of a verb and its arguments or adverbials or both. As the Vendler and Dowty system understands the classification in terms of lexical properties of individual verbs, we shall adopt their classification in describing the four lexical classes of verbs for their interaction with aspect markers. At the level of states of affairs, we shall apply the classes distinguished by Sasse (1991) because it would otherwise be impossible to describe how aspect markers interact with states of affairs with only an initial boundary.

\section{Previous studies of aspect in}

Thai

Compared to several other grammatical categories in Thai grammar, aspect has been studied by few grammarians and linguists. Most of these works treat aspect as one topic among others within the description of the whole language or within a complete study of syntax. Despite their brevity, they provide informative descriptions of aspect in Thai. Among these are Noss (1964), Panupong (1970), and Warotamasikkhadit (1972). Works which deal particularly with aspect in Thai are few. We will review two of them in this section: the one by Boonyapatipark (1983), and the other by Sookgasem (1990).

Based mainly on Lyons (1977) and also on Vendler (1967), Boonyapatipark (1983), in her dissertation entitled 'A Study of Aspect in Thai', proposes two main types of situations: static and dynamic. She subdivides static situations into permanent and temporary situations. Dynamic situations are subdivided into two types: processes and events; then processes are further subdivided into nonaccomplishments and accomplishments; for event types, she proposes two subtypes: achievement and momentary, the latter sub-class being her own. Momentary events are described as situations which cover a very short period of time and the verbs used to express these situations can co-occur with progressive and continuative markers. Boonyapatipark thus has identified altogether six types of situations: permanent state, temporary state, accomplishment, non-accomplishment, achievement and momentary. With these six types of situations, Boonyapatipark also proposes six verb classes under the condition that these verbs occur in a simple sentence with no modifying unit like adverbials or aspect markers. Such a condition implies that the classification is based on inherent features. But Boonyapatipark's third major type which she calls "verbs indicating either a dynamic situation or a state resulting from the completion of a dynamic situation" indicates that a lot of verbs in Thai cannot be exclusively classified as "dynamic" or "state" verbs but they can be either, depending on the environment in which they occur. In khăw pìt pràtuu 'He closes the door.' pit is a verb indicating a dynamic situation but in pràtuu pìt 'The door is closed.' pit is a verb indicating a state. The adequate interpretation depends on the animacy of the subject of the sentence.

This category of "verbs indicating dynamic situations or states arising from such situations" is typologically the most interesting. It seems to be typical of Southeast Asian languages that some verbs can belong to different verb classes and that it is basically context which 
decides which interpretation actually applies.

Boonyapatipark's contribution to a study of aspect is based on her careful examination of the occurrences of each of the six aspect markers: yùu, yay, lécw, khəəy, cà? and kamlan with the different types of verbs classified above. For example, kamlan as a progressive aspect marker, usually cooccurs with verbs indicating dynamic situation but not with verb indicating achievement situations. Therefore * năn kamlay còp 'the movie is ending' is not acceptable in Thai because còp is a verb indicating achievement.

However we find that a sentence such as năy kamlan cà? còp lécw 'The movie is about to end.' is well accepted. Probably this is due to the fact that Boonyapatipark's framework only allows her to talk about the lexical temporal structures of verbs but not the temporal structure of state of affairs. kamlan cà? còp is an example of a move towards the terminative state of affairs.

Boonyapatipark refers to terms such as progressive, completive, perfective when she talks about aspect markers. Sometimes, she uses these terms to refer to situations, too. It is not clear how these aspectual features of the aspect markers interact with the six types of situations she sets up.

The second work that we would like to mention is Sookgasem's dissertation (1990) entitled "Morphology, Syntax and Semantics of Auxiliaries in Thai". In this work, Sookgasem dedicates a whole chapter to aspect which she calls "eventualities". She defines eventualities or aspect in terms of Johnson (1981). Thus, the concept of eventualities "involves the idea of temporally distinct phases of an event, which are to be understood broadly as encompassing the whole sequence of an event's evolution through time. That is, the phases of an event begin with the earliest time that the event may be taken to be concrete reality in the projected course of events, and lasts until the latest time that the event continues to affect the shape of later events. Consequently, the phases of an event include times that are strictly earlier or later than the time of the event itself." It is apparently the last sentence of the definition that lets Sookgasem talk about the initial point and final point of an event. Another point that should be noted is that according to her, eventualities can be expressed at all levels from lexical word to verb phrase and sentence. This means that aspectual meaning is not only indicated within the lexical word but also by the co-occurrences of a verb and temporal expressions and aspect markers. Sookgasem divides verbs into nontemporal verbs such as nân 'to sit', dəə⿱亠䒑 'to walk' and temporal verbs which are more or less equivalent to auxiliaries used by other linguists. She proposes that these temporal verbs have certain aspect elements of their own, for example, rồm 'to begin' has an inchoative element; $1 \varepsilon \varepsilon w$, a perfective element; kamlan, a progressive element; ph̀̀n cà? sèt, a postcompletive element. She then examines the occurrences of these temporal verbs with the types of aspect introduced by Vendler (1967): state, activity, accomplishment, and achievement. The temporal verb kamlan which is the progressive aspect verb, for example, cannot occur with a certain type of state. The temporal verb sèt which highlights or 
establishes a terminal boundary, cannot occur with the copula verb pen 'be' as in *khăw pen khon sèt léEw [he be person stop ASP]. Sookgasem then investigates the four situation types at the sentence level, considering, for example, the plurality and singularity of the subject of the sentence with achievements. When it comes to non-temporal verbs, it is not clearly presented how types of situation and temporal aspect verbs are dealt with in relation to them.

\section{Classification of verbs and states of affairs}

In this section, we shall first look at classes of verbs based on their inherent temporal properties as described by Vendler (1967). Secondly, we will examine derived temporal structures and derived classes of states of affairs which are the result of the use of strategies for manipulating the temporal structure of states of affairs beyond the lexical properties of the verbs.

\subsection{Temporal structures inherent to} the verbs
All the four following classes of verbs can be distinguished:

\subsubsection{State verbs}

At the lexical level, state verbs can be identified by the semantic feature [+static, -telic, -punctual]. Some examples of state verbs are pen 'to be', mii 'to have', khĚn 'to be hard', kròot 'to be angry', rák 'to love', khâwcaj 'to understand'.

The following illustrates these verbs in sentences:

(2) khon thay rák bâan kòot person-Thai-love-homeland 'The Thai people love their homeland.'

\section{(3) hĭn khěn máay Pjòn} stone-hard-wood-soft 'Stone is hard, wood is soft.'

(4) $m \hat{\varepsilon} \varepsilon$ pen khon cay dii mother-be-person-heart-good 'Mother is a kind person.'

If we use the test in Table 2, we will get the following results as expected:

\begin{tabular}{|c|c|c|}
\hline & & $\begin{array}{l}\text { State Verb } \\
\text { khěn 'to be hard' as in } \\
\text { hǐn khع̌n 'Stone is hard' }\end{array}$ \\
\hline 1 & Occurs with progressive & - \\
\hline 2 & $\begin{array}{l}\text { Occurs with adverbs like yàa khěøn khăn } \\
\text { 'actively' }\end{array}$ & - \\
\hline 3 & $\begin{array}{l}\text { Occurs with adverbs like } \\
\text { yàan rûatrew 'quickly }\end{array}$ & - \\
\hline 4 & $\begin{array}{l}\text { Occurs with time adverbials like } \\
\text { pen chûa moon. 'for an hour' }\end{array}$ & - \\
\hline 5 & $\begin{array}{l}\text { Occurs with time adverbials like } \\
\text { nay nin chûa moon 'in an hour' }\end{array}$ & - \\
\hline
\end{tabular}

Table 5. Example of state verb in Thai with identification criteria 


\subsubsection{Activity verbs}

Activity verbs are identified by the semantic features [-static, -telic,-punctual]. Some examples of activity verbs are doan 'to walk' khuy 'to chat' Paan. 'to read'. Some examples of these verbs in sentences follow:
(5) khăw dəon lên he-walk-play 'He takes / is taking a stroll.' khăw khuy kan

they-chat-each other 'They chat (with each other).'

\section{(7) khăw. Pàan năgsǔt she-read-book 'She is reading / read}

If we use the test in Table 2, we will get the following results as expected:

\begin{tabular}{|c|c|c|}
\hline & & $\begin{array}{l}\text { Activity Verb } \\
\text { dəən 'to walk' as in } \\
\text { khăw dəən lên } \\
\text { 'He is taking a stroll.' }\end{array}$ \\
\hline 1 & Occurs with progressive & $\checkmark$ \\
\hline 2 & 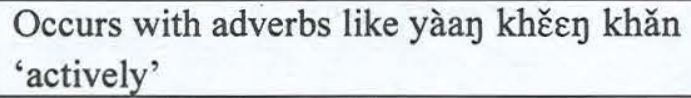 & $\checkmark$ \\
\hline 3 & $\begin{array}{l}\text { Occurs with adverbs like } \\
\text { yàan rûatrew 'quickly }\end{array}$ & $\checkmark$ \\
\hline 4 & $\begin{array}{l}\text { Occurs with time adverbials like } \\
\text { pen chûa moon 'for an hour' }\end{array}$ & $\checkmark$ \\
\hline 5 & $\begin{array}{l}\text { Occurs with time adverbials like } \\
\text { nay nün chûa moon 'in an hour' }\end{array}$ & - \\
\hline
\end{tabular}

Table 6. Example of activity verb in Thai with classification criteria

\subsubsection{Accomplishment Verbs}

Accomplishment verbs are identified by the semantic features [-static, +telic, -punctual]. There is only a small number of verbs belonging to this class for examples, tàt $s \hat{t} a$ 'to make dress' sàrùp 'to draw a conclusion, to conclude', rahə̌əy 'to vaporize'. Examples of accomplishment verbs: tàt $s \hat{\text { taa }}$ 'to make dress', sàrùp 'to conclude', in sentences follow:

khăw tàt stâa Peeந she -make -dress -self 'She makes her own clothes.'

raaynaan cà sarùp phrûnníi report-will-conclude-tomorrow 'Work / report will be concluded tomorrow.' 
Compared to other verb classes, inherent accomplishment verbs are quite rare in Thai. It seems that in Thai inherent action verbs are generally used with object noun phrases or adverbials to indicate accomplishment situation: khăw khřan nănsǔu còp lécw [he write book finish ASP], "He finished writing his book."

If we use the test in Table 2, we will get the following results as expected:

\begin{tabular}{|c|c|c|}
\hline & & $\begin{array}{l}\text { Accomplishment Verb } \\
\text { sarup 'to conclude' as in khăw sarüp } \\
\text { léwW } \\
\text { 'he concluded already' }\end{array}$ \\
\hline 1 & Occurs with progressive & $\checkmark$ \\
\hline 2 & 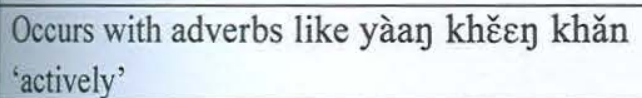 & - \\
\hline 3 & $\begin{array}{l}\text { Occurs with adverbs like } \\
\text { yàan rûatrew 'quickly }\end{array}$ & $\checkmark$ \\
\hline 4 & $\begin{array}{l}\text { Occurs with time adverbials like } \\
\text { pen chûa moon 'for an hour' }\end{array}$ & irrelevant \\
\hline 5 & $\begin{array}{l}\text { Occurs with time adverbials like } \\
\text { nay nìn chûa moon 'in an hour' }\end{array}$ & $\checkmark$ \\
\hline
\end{tabular}

Table 7. Example of accomplishment verb in Thai with classification criteria

\subsubsection{Achievement verbs}

Achievements verbs can be identified by [-static, +telic, +punctual]. The following verbs belong to this class: sèt 'to be finished', thüry 'to reach', taay 'to die'.

(10) Jaan khǒon khăw sèt Paw naathii sùttháay work-of-he-finish-minute-last 'His work was finished in the last minute.'

If we use the test in Table 2, we will get the following results as expected: 


\begin{tabular}{|l|l|c|}
\cline { 3 - 3 } \multicolumn{2}{l|}{} & $\begin{array}{l}\text { Achievement Verb } \\
\text { sèt 'to finish' as in gaan sèt } \\
\text { 'The work is finished' }\end{array}$ \\
\hline 1 & Occurs with progressive & - \\
\hline 2 & $\begin{array}{l}\text { Occurs with adverbs like yàan khěघn khăn } \\
\text { 'actively' }\end{array}$ & - \\
\hline 3 & $\begin{array}{l}\text { Occurs with adverbs like } \\
\text { yàan rûatrew 'quickly }\end{array}$ & $-*$ \\
\hline 4 & $\begin{array}{l}\text { Occurs with time adverbials like } \\
\text { pen chûa moon 'for an hour' }\end{array}$ & - \\
\hline 5 & $\begin{array}{l}\text { Occurs with time adverbials like } \\
\text { nay nùn chûa moon 'in an hour' }\end{array}$ & $-*$ \\
\hline
\end{tabular}

Table 8. Example of achievement verb in Thai with classification criteria

\subsubsection{Some generalizations about verb classes in Thai}

Of the four verb classes suggested by Vendler (1967), two cover a large number of verbs in Thai (i.e. state verbs and activity verbs) and two consist only of a comparatively small number of entries (i.e. verbs of achievement and verbs of accomplishment). Besides, a number of verbs do not adhere to just one verb class. Thus, the following verbs can either be understood as activities or as states:

(11) sày stûa

put on/wear-shirt

1 'to wear (state)'

2. 'to put on (activity)'

(12) pit

close

1. 'be closed (state)'

2. 'to close (activity)'

(13) pə่̀t

open

1. 'to be open (state)'

2. 'to open (activity)'

\subsection{Derived temporal structures and derived classes of states of affairs}

There is quite a number of strategies for manipulating the temporal structure of states of affairs beyond the lexical temporal structure of individual verbs. If a state of affairs consists of just the verb, it is the lexical boundary structure of that verb which interacts with aspect operators. However, if more information is overtly added, the temporal structure of the verb can be overridden.

Here, we would like to enumerate the following strategies for adding information on to the temporal structure of a state of affairs beyond the lexical properties of the verb:

\section{Directional verbs with certain stative verbs \\ Resultative verbs \\ Adverbials that add temporal boundaries or change a verb with boundaries into a state}


Quantified arguments

The use of phasal verbs/phasal markers

The addition of terminal markers

The following examples illustrate how additional information introduced by the above strategies produces states of affairs whose temporal structures clearly differ from the temporal structure as it is determined by the inherent temporal structure.

\subsubsection{Directional verb strategy}

With directional verbs kht̂n 'up' or lon 'down', we can get dynamic inceptivestative state of affairs with lexically stative main verbs:

(14) ?uân khên

fat-up

'getting fat'

(15) phวัsm lon

thin-down

'getting thin'

\subsubsection{Resultative verb strategy}

With resultative verbs such as Pim 'to be full' or ?jok 'to be out', we can get terminative state of affairs with an action verb as the main verb.

(16) Kin Pim

eat-full

'eat to one's fill'

\author{
khít ?’̀ok \\ think-out \\ 'get a solution'
}

\subsubsection{Temporal-adverbial strategy}

With certain temporal adverbials such as

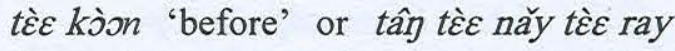
'from time unknown' we can get, stative state of affairs with action verbs as main verb.

$$
\begin{aligned}
& \text { khon thay kin khâaw tân } \\
& \text { tèc nayy tè } \text { ray } \\
& \text { people-Thai-eat-rice-since- } \\
& \text { where-since-when } \\
& \text { 'Thais eat rice from time } \\
& \text { unknown.' }
\end{aligned}
$$

\subsubsection{Quantified argument strategy}

With quantified phrase such as săam chobàp 'three letters' we can get terminative states of affairs with action verbs as main verbs.

$$
\begin{aligned}
& \text { khǎw khǐan còtmǎay sǎam } \\
& \text { chəbàp } \\
& \text { she-write-letter-three-Clf. } \\
& \text { 'She has written three letters.' }
\end{aligned}
$$

\subsubsection{Phasal verb strategy}

With phasal verbs like rôəm 'to begin, to start' we can get inceptive-stative state of affairs with lexically stative main verbs.

\section{náam râəm khěn}

water-start-hard

'The water is freezing.' 


\subsubsection{Addition of terminal marker strategy}

With certain terminal markers such as còp 'to end', we can get terminative state of affairs with action verb as the main verb.

\section{(21)}

\section{khăw khřan năysǔu còp he-write-book-finish \\ 'He finished writing his book.'}

\section{Types of Aspect}

If one looks at the aspectual system of Thai as a whole, there seems to be four layers. The first layer is based on the inherent temporal structure of the verb (see 4.1), the second on the temporal structure of the entire state of affairs and the strategies to manipulate temporal structure (see 4.2). On the third layer which will be discussed in 5.1, we find the individual aspectual markers as they interact with the semantics of the first two layers. At the fourth layer which will be the topic for 5.2, we will deal with combination of aspect markers. The mere fact that temporal markers can be combined does not sound possible if one thinks in terms of the classical aspectual functions of perfective vs. imperfective which are complementary and thus mutually exclusive in the classical aspect languages.

Since aspect crucially depends on the interaction of aspect markers with the temporal semantics of verbs or states of affairs, we do not need to discuss each class of states of affairs in detail in this paper. Instead, we would like to discuss how an aspectual marker with its particular semantic properties reacts if it is applied to a situation with no temporal boundary or to a situation with an initial boundary or with a terminal boundary that includes the distinction between graduall and totally terminative or with bot boundaries. It is for that reason that in 5 . we will not strictly distinguish whether a temporal boundary is provided by the lexicon discussed in 4.1 or by one of the derivational strategies discussed in 4.2 .

\subsection{The three aspect markers lécw, yùu and kamlan}

\subsubsection{The aspect marker léEw}

The aspect marker $l \varepsilon \varepsilon \mathcal{E} W$ highlights a time boundary either the initial or the terminal one. If it interacts with the initial boundary, it expresses change to a new situation. If it interacts with a terminal boundary, it indicates that "a crucial amount of some activity has been reached" (See Boonyapatipark 1983:158. 159).

It should be noted that the tempora boundary is either part of the state of affairs, (lexically in subsection 4.1 or by one of the strategies mentioned subsection 4.2) or it is established by lécw. We first look at those instances in which léEW operates on temporal boundaries which are part of a given state of affairs. With inceptive-stative states of affairs and with terminative states of affairs, gradually as well as totally terminative ones, lécW operates only on the existing temporal boundaries. In the following analysis, we will follow this order: with existing temporal boundaries. either initial or terminative $\left[\mathrm{SC}_{1} \mathrm{~S} ; \mathrm{SCS}_{3}\right.$ ] with both temporal boundaries [ $\mathrm{CS}_{1} \mathrm{SC}$ ] and no temporal boundary $[\mathrm{S}]$. 


\section{Inceptive-stative (ISTA) [CS 1 S]}

(22) With the resultative verb khâw 'to enter' expressing the initial boundary:

phǒm rák thəə khâw lécw

I-love-she-enter-ASP

'I have fallen in love with her (before I did not love her but now I do)

(23) With the directional verb kht̂nn 'to go up'

expressing the initial boundary:

Paakàat róon kht̂n lécw.

weather-hot-up-ASP

'The weather has started to become hot (the temperature did not increase before but now it is doing so).'

\section{Gradually terminative (GTER) [S CS2]}

(24) With a resultative verb ?’ok 'to be out' expressing the terminative boundary.

\section{khăW khít Pòok léew}

he-think-out-ASP

'He saw a solution (he was thinking about the solution and the phase of looking for a solution came to a successful end).'

(25) With locative adverbial thŭg bâan 'reaching home' expressing the terminative boundary.

\author{
khăw doən thŭn bâan lécw \\ he-walk-reach-home-ASP \\ 'He has reached home (the process \\ of walking home has come to a \\ terminal point).'
}

\section{Totally terminative (TTER) [ $\left.\mathrm{CS}_{2}\right]$}

With an achievement verb sèt 'to be finished' expressing the terminative boundary.
நaan sèt lécW work-finish-ASP
'The work is/was finished (end of the work is achieved).'

\section{Action (ACTI) $\left[\begin{array}{lll}\mathrm{CS}_{1} & \mathrm{~S} & \mathrm{CS}_{2}\end{array}\right]$}

Action states of affairs can be ambiguous due to the presence of two boundaries. Thus, in (27b) we get a completive interpretation if $l \varepsilon \varepsilon \mathcal{E} W$ applies to the terminal boundary. If it applies to the initial boundary as in (27a), we get an inchoative interpretation. If $1 \varepsilon \dot{\varepsilon} w$ applies to the situation between the two boundaries we get an interpretation in which a change of state takes place with regard to the object of the verb (before, he ate, but he did not eat rice). This interpretation is possible because khâaw 'rice' is taken as the object of the verb kin 'eat' and is focused, whereas it is incorporated with kin in (27a) and (27b).

$$
\begin{aligned}
& \text { khăw kin khâaw lécw } \\
& \text { he-eat-rice-ASP } \\
& \text { a. (Inchoative): 'He has started } \\
& \text { eating.' } \\
& \text { b. (Completive): 'He has } \\
& \text { finished eating.' }
\end{aligned}
$$


c. (Change of State): 'He eats rice now, before he ate something else.

\section{State (TSTA) [S]}

With simple state verbs, there is no temporal boundary for $l \varepsilon \varepsilon w$ to interact with. Thus, it is used to establish a temporal boundary. The establishment of such a boundary implies a change of state as in the following example:

\section{Paakàat róon lécw weather-hot-ASP \\ 'The weather became hot.'}

\subsubsection{The aspect marker yùu}

Boonyapatipark (1983) describes the function of yùu as follows:

" $\ldots$ with the use of yùu, the speaker can be said to view a situation as accumulating through time. The situation referred to is normally thought of as starting some time before a particular point in time which will be taken to be the time of speech unless otherwise indicated, and as continuing until some time afterwards. An exception to this generalization would be the case where a specific duration of time is given within which a situation lasts. In such a case the situation will be viewed as continuing through that time."

(Boonyapatipark, 1983: 110111).
In our view, accumulating through time is not necessarily involved with yùu. The marker yùu describes that a situation is continuous through time or along time without reference to boundaries. For that reason yùu cannot operate on temporal boundaries and thus it is incompatible with inceptive-stative and with terminative states of affairs. With action states of affairs, the interaction is different because here yùu can operate on the phase between the initial and the terminal boundaries.

yùu is not compatible with a noncontinuity state over time or a generic state. ${ }^{4} \quad$ This is the reason why yù may not co-occur with preverbs like mák cà? 'often, usually' or adverbials like taam thammadaa 'usually' which convey the meaning of non-continuity, for example, the sentence *khon thay mák cà? kin khâaw yùu is not possible. The continuity of the situation expressed by yùu does not imply permanence. Given its temporary meaning, yùu is thus incompatible with generic statements. Therefore, a sentence

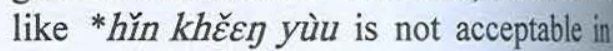
Thai. In the rest of this section, we look at the compatibility of different types of states of affairs with yùu.

4 In khăw mák ca? 3ojok kamlan yù toon cháw chaw (he-usually-exercise-Asp -in the morning) ' $\mathrm{He}$ is usually doing a body exercise in the morning', a time reference is given. This makes the state of affairs non generic and yiu can therefore occur with mak ca?? 


\section{Totally stative [S]}

yìu can occur with state verbs giving stative state of affairs.

(29) khăw pen khruu yùu he-be-teacher-ASP ' $\mathrm{He}$ is a teacher (from the perspective of the speech act time he has been a teacher and continues to be a teacher. However this state may not last forever).'

(30) khăw pen khruu yùu toon níi he-be-teacher-ASP-moment-this ' $\mathrm{He}$ is a teacher right now (his being a teacher is going on at the particular moment but it may not last forever).'

(31) khăw pen khruu yùu toon nán he-be-teacher-ASP-moment-that 'He was a teacher at that time (his being a teacher was continuous at the reference time but not at the speech act time).'

\section{Action (ACTI) [CS1 S CS2]}

With activity verbs, for examples:

(32) Khăw Pàan năysǔu yùu he-read-book-ASP

'He is reading a book (the phase of his reading a book continues through time for a while).'

\section{Inceptive-stative (ISTA) [CS1 S]}

yùu cannot co-occur with inceptive stative verbs/states of affairs:
(33)

*phǒm rák thəə khâw yùu

I-love-she-in-ASP

'I fell in love with her.'

* Paakàat róon maa sǒon săam wan yùu weather-hot-come-two-three-dayASP 'It became hot for two days.'

*khăw rôsm thamjaan yùu He-start-work-ASP 'He started working.'

\section{Gradually terminative (GTER) [S CS2]}

yùu cannot occur with gradually terminative state of affairs:
* raw kin Pim yùu
we-eat-be-full-ASP
'We are eating to our fill.'

Note that this sentence can be spoken by Thai native speakers as the answer to the question 'Do you have enough?' The answer indicates that the speaker does not exactly have enough but more or less. Observe that yùu in this sentence does not give any aspectual meaning (see also sentence 41).

$$
\begin{aligned}
& \text { *khăw khřan còp yùu } \\
& \text { he-write-finish-ASP } \\
& \text { 'He finished writing.' } \\
& \text { *khǎw sòn còtmǎay mòt yùu } \\
& \text { he-send-letter-finish up-ASP } \\
& \text { 'He sent all letters.' }
\end{aligned}
$$




\section{Totally terminative (TTER) $\left[\mathrm{CS}_{2}\right]$}

yùu can neither occur with totally terminative states of affairs. Thus, it cannot occur with an achievement verb like taay'to die':

\section{*khăw taay yùu \\ he-die-ASP \\ 'He was dead.'}

However, totally terminative states of affairs are compatible with yùu if the achievement verbs imply consecutive occurrences as in the following example.

$$
\begin{aligned}
& \text { pám náamman rabòot yùu } \\
& \text { filling station-explode-ASP } \\
& \text { 'The filling station is exploding. } \\
& \text { (There is a series of explosions } \\
& \text { involved.)' }
\end{aligned}
$$

The marker yùu allows a pragmatic extension of its meaning beyond the domain of time if used with qualitydenoting states. From the temporary states of a given quality, it is inferred that the quality itself is somewhat reduced. Thus in an example like (41) one can infer that this meal does not exhaustively meet the standard associated with the qualitative state of Pàròy.

\section{Paahăan Pàròy yùu meal-be delicious-ASP 'The meal is quite good.'}

\subsubsection{The aspect marker kamlan}

We agree with Boonyapatipark that kamlan marks a state of affairs which is in progress at reference time. Since this marker crucially depends on a potential time span to which it can apply, it is incompatible with states of affairs whic have no situation (S). As in the case of yùu, kamlay is not compatible with modal markers such as mák cà? 'often' and with adverbials such as taam thammadaa 'usually' and with generic statements for the same reasons. Thus, a sentence like *khon thay mák cà? kamlan kin khâaw [people Thai often PROGR eat rice] is impossible. In the rest of this section, we look at the compatibility of different types of states of affairs with kamlan.

\section{Totally stative (TSTA) [S]}

In the case of totally stative of affairs, if the situation does not specify reference time kamlan is incompatible with totally stative states of affairs. Thus, example (43) and (44) are ungrammatical because they are generic statements and thus do not convey any specific reference time for kamlan to operate on.

Paakàat kamlan róon. weather-ASP-hot '(At reference time) the weather is ho.

\section{*ȟ̆n kamlan khěn} stone-ASP-hard

"*Stone is being hard (impossible because 'Stone is hard.' is a generic statement where no reference time is indicated.)'

* khon thay kamlan rák bâan kə̀ət people-Thai-ASP-love-homeland "*Thai people are loving their homeland (impossible because 'Thai people love their homeland' is a generic statement where no reference time is indicated.)' 


\section{Inceptive-stative (ISTA) $\left[\mathrm{CS}_{\mathbf{1}} \mathrm{S}\right]$}

The progressive marker kamlan is compatible with inceptive-stative states of affairs:

(45) Paakàat kamlan yen lon. weather-ASP-cool-down 'At reference time) the weather is in the process of getting cooler.'

\section{Action (ACTI) [CS $\left.1 \mathrm{~S} \mathrm{CS}_{2}\right]$}

The progressive marker kamlay is compatible with action states of affairs:

(46) Khǎw kamlay Pàan năysǔu. he-ASP-read-book 'He is reading a book (at reference time the action of reading is going on).'

\section{Gradually terminative (GTER) [S CS2]}

The progressive marker kamlan is compatible with gradually terminative states of affairs:

(47) khăw kamlā khón

phóp wayrás tua mày

he-ASP-discover-virus-Clf-new

'They are discovering a new virus (at reference time the process of discovering a new virus is going on aiming at the terminal point).'

\section{Totally terminative (TTER) [CS2]}

As the totally terminative has no [S], kamlag is incompatible.
(48)

\section{*khăw kamlay taay \\ he-ASP-die}

'He is dying (impossible because achievement verbs convey a situation at the point of time whereas kamlay conveys a situation in progress).'

For some Thai speakers, this sentence is acceptable but with the meaning 'he is going to die,' for which the more appropriate and more acceptable sentence is khăw kamlan cà? taay (he-ASP-willdie).

\subsection{Combination of aspect markers}

Aspect markers can be used cumulatively. As we pointed out, this is remarkable because in aspect languages with a binary aspectual system (perfective vs. imperfective), aspect markers are complementary.

The compatibility of aspect markers depends on the type of states of affairs (totally stative, inceptive-stative, etc.) plus the semantics of the aspect markers involved. As for the mutual compatibility of aspect markers, there are three general rules:

(a) The two markers kamlay and léw are mutually exclusive and thus incompatible if they operate on the same temporal unit because lécW refers to a point in time, while kamlan refers to a time span. To be more precise, lécw operates on time boundaries from a punctual perspective, while kamlay points out that a given state of affairs is in progress at reference time. (The reason why 
kamlay and lécw can co-occur with inceptive states of affairs is given in section 5.2.3., cf. example 51(d)).

(b) When the boundary marker cà? is introduced, it provides a very short span before the initial boundary marked by lécw. kamlay and cà? interact with this short span towards the initial boundary marked by lécw. Thus, incompatibilities among aspect markers can be cancelled.

(c) More than two aspect markers can occur only if the marker cà? is involved.

In the rest of this section, we look at the five types of states of affairs and patterns of multiple aspect marking.

\subsubsection{Combination of aspect markers with a totally stative state of affairs:}

\section{a. náam róon \\ water-hot \\ 'The water is hot.'}

The sentence is said when one touches the cup of hot water.

b. Progressive + Continuative: náam kamlan róon yùu water-ASP-hot-ASP 'The water is being hot (now, but may be not so later).' The sentence conveys the same state of affairs as the one in sentence (42)

c. Continuative + lécw. náam róon yùu lécw water-hot-ASP-ASP
'The water is hot.'

The sentence is said when someone tells the hearer to heat the water and $s / h e$ thinks it is already hot, i.e., no reheating is needed. lécw sets a boundary and yùu marks that the state of hotness continues in that temporal boundary.

d. Progressive $+1 \varepsilon \varepsilon \varepsilon w$. * náam kamlan róon léew water-ASP-hot-ASP Incompatibility of the two markers; See Rule (a) above.

e. Progressive + Continuative + lécw.

*náam kamlạ róon yùu léeW

water-ASP-hot-ASP-ASP

Incompatibility of the two markers; See Rule (a) above.

f. Progressive + marker cà?+ Continuative $+1 \varepsilon \varepsilon w$. náam kamlan cà? róon (yùu) lécW water-ASP-cà?-hot-ASP-ASP 'The water is about to become hot.'

The marker cà? explicitly introduces a short temporal span before an initial boundary. The marker $1 \varepsilon \varepsilon w$ operate on the initial boundary, which it introduces in the case of stative states of affairs. lécw expresses the imminent change of state at this initial temporal boundary after the very short span introduced by cà? The other two markers kamlay and yùu also operate on this very short span. 


\subsubsection{Combination of aspect markers with an action state of affairs:}

(50) a. yaay kamlan kin khâaw grandma-ASP-eat-rice 'Grandma is eating'

b. Progressive + Continuative: yaay kamlan kin khâaw yùu grandma-ASP-eat-rice-ASP 'Grandma is eating [the action is progressing at reference time.]'

c. Continuative $+1 \varepsilon \varepsilon \varepsilon w$. yaay kin khâaw yùu lécw grandma-eat-rice-ASP-ASP 'Grandma is eating now.'

The doctor tells the speaker to make it possible to have grandma eat and $s /$ he then tells the doctor that there is no need to worry because grandma is eating/has been eating. lécw refers to an initial boundary of kin 'to eat' and the action continues from that time boundary.

d. Progressive + lécw: *yaay kamlan kin khâaw léeW

grandma-ASP-eat-rice-ASP

Incompatibility of the two markers; See Rule (a) above.

e. Progressive + Continuative + léew:

*yaay kamlan kin khâaw yùu lécW grandma-ASP-eat-rice-ASP-ASP Incompatibility of the two markers; see Rule (a) above. f. Progressive + marker cà? + Continuative $+1 \varepsilon \dot{\varepsilon} w$ yaay kamlan cà? kin khâaw yùu lécw grandma-ASP-cà? -eat-rice-ASPASP Grandma is going to eat rice right now.

Here again, the marker cà? introduces an imminent temporal span before the initial boundary. lévw operates on the initial boundary. The other two markers kamlan and yùu also operate on the very short span before the initial boundary.

\subsubsection{Combination with an inceptive- stative state of affairs}

Combinations with yùu plus inceptivestative states of affairs are not possible (see section 5.1.2.). Thus sentences 51(b), (c) and (e) below are not possible. The combination of progressive plus lécW in $51(d)$ is possible. This is due to the fact that $l \varepsilon \varepsilon w$ and kamlan do not refer to the same temporal unit. The progressive marker operates on the temporal phase introduced by the resultative verb khtun 'go up', while the marker léEW expresses a change of state with the stative verb róon 'be hot'.

(51)a. náam róon kht̂̂n.

water-hot-up

'The water is becoming hot.'

b. Progressive + Continuative:

* náam kamlan róon kht̂n

yùu 
c. Continuative + lé $\varepsilon w$.

* náam róon kht̂n yùu léew

d. Progressive $+1 \varepsilon \varepsilon \varepsilon w$. náam kamlan róon kht̂n lécw. water-ASP-hot-up-ASP 'The water's becoming hot already'

e. Progressive + Continuative + lécW:

*náam kamlan róon kht̂nn yùu lécw water-ASP-hot-up-ASP-ASP In contrast to the following example, this sentence is not possible because of rule (c)

f. Progressive + marker cà? + Continuative + lé $\varepsilon W$ náam kamlan cà? róon kht̂̂n yùu lécw water-ASP-cà? -hot-up-ASP-ASP 'The water is getting hot.'

\subsubsection{Combination with a gradually terminative state of affairs}

Since yùu is not compatible with gradually terminative states of affairs (cf. section 5.1.2), sentences 52(b), 52(c), and 52(e) are not possible. In contrast to 51(d), 52(d) is ungrammatical. This is due to the fact that resultative verbs like $2 \mathrm{jok}^{\prime}$ 'move out' combined with an action verb like khit 'think' do not seem to introduce a new phase as is the case with khtun 'go up' with stative verbs as in 51(d) but rather highlight the terminal boundary. Thus, there is only one temporal boundary in 52(d), i.e., the terminal boundary, which cannot be operated on by two mutually exclusive markers.
(52) a. yaay khít Pذ̀ok lécW grandma-think-out-ASP 'Grandma found a solution.'

b. Progressive + Continuative: *yaay kamlan khít ?’ok yùu Grandma-ASP-think-out-ASP

c. Continuative + lécw. * yaay khít ?òsk yùu lécw Grandma-think-out-ASP-ASP

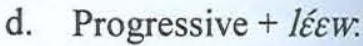
*yaay kamlan khít ?jok lécw. grandma-ASP-think-out-ASP

'Grandma was finding a solution [She was thinking], This sentence is not possible although 2jok sets a terminative boundary for lés, but rule (a) cannot be violated.

e. Progressive + Continuative + lécw.

* yaay kamla刀 khít ?j̀k yùu lécw

Grandma-ASP-think-out-ASP. ASP

This sentence is not possible because of rule (c).

f. Progressive + marker cà? + Continuative $+1 \varepsilon \varepsilon w$ yaay kamlā cà? khít ?’̀̀k yùu léew grandma-ASP-cà? -think-outASP 'Grandma is close to find a solution.' 
In example (f) the marker cà? introduces a boundary before the terminative boundary lécw. This allows a possible span for kamlay and cà? to interact with.

\subsubsection{Combination with a totally terminative state of affairs :}

Since an achievement verb with a totally terminative state of affairs does not cooccur with kamlan and yùu, sentence 53(b), (c), (d), (e) and (f) are not acceptable.

(53) a. khăw taay lécw he-die-ASP 'He died.'

b. Progressive + Continuative: *khǎw kamlan taay yùu He-ASP-die-ASP

c. Continuative $+1 \varepsilon \varepsilon w$. *khăw taay yùu lécw He-die-ASP-ASP

d. Progressive + lécw: *khăw kamlan taay lécw He-ASP-die-ASP-ASP

e. Progressive + Continuative + léew.

*khăw kamlan taay yùu lécW He-ASP-die-ASP-ASP

This sentence is not possible because of rule (c).

f. Progressive + marker $c a ̀ ?+$ Continuative *khăw kamlay cà? taay yùu

He-ASP-cà? -die-ASP

$\mathrm{He}$ is close to die./

$\mathrm{He}$ is dying.

g. Progressive + marker cà? + lécw.

khăw kamlan cà? taay lè $\mathcal{E} W$ he-ASP-cà? -die-ASP

' $\mathrm{He}$ is going to die (anytime now.)'

h. Progressive + marker cà? + Continuative +lécw khăw kamlan cà? taay yùu lé $\varepsilon W$ he-ASP-cà? -die-ASP-ASP ' $\mathrm{He}$ is going to die any minute:'

cà? again establishes a temporal span by which the two aspect markers kamlan and yùu is possible

With achievement verbs like rabə̀ot 'to explode' which allow the consecutive occurrences of totally terminative states of affairs, a combination of kamlan and yùu may be possible:

pám námman kamlan rab̀̀ot yùu filling station-ASP-explode 'The filling station is exploding.'

The following table summarizes the possible combinations of aspect markers in different states of affairs presented above: 


\begin{tabular}{|c|c|c|c|c|c|}
\hline & State & Action & $\begin{array}{l}\text { Inceptive- } \\
\text { Stative }\end{array}$ & $\begin{array}{l}\text { Gradually } \\
\text { Termina- } \\
\text { tive }\end{array}$ & $\begin{array}{l}\text { Totally } \\
\text { Termina } \\
\text { tive }\end{array}$ \\
\hline kamlay + yùu & + & + & - & - & . \\
\hline yùu + lécw & + & + & - & - & - \\
\hline kamlan + lécw & - & - & + & - & - \\
\hline kamlay + yùu + lécw & - & + & - & - & - \\
\hline kamlag + cà? + yùu + lécw & + & + & + & + & + \\
\hline
\end{tabular}

Table 9. Summary of combinations of aspect markers

From the data presented in sections 5.2.15.2.5 and from Table 9 above we can draw out the following points:

1. If there are any two aspect markers involved, the following combinations are allowed:

$$
\begin{aligned}
& \text { i) kamlan + yùu } \\
& \text { ii) yùu + lécw }
\end{aligned}
$$

The combination of kamlay and lécw is ungrammatical if only two aspect markers are involved. cà? as a boundary marker must be introduced. Aspect markers must always occur in the order indicated in i) and ii). While kamlan is preverbal yùu and lécW are postverbal.

\section{The fact that yùu and lécw can} co-occur while kamlay and lécw are mutually exclusive points to an important difference between yùu and kamlan. While both mark a time phase, kamlay seems to convey progression at reference time (most naturally at the speech act moment), while yùu does not make any reference to a point in time. The marker yùu only conveys a continuous situation through time. Thus, kamlay is not compatible with $l \varepsilon \varepsilon w$ which highlights or sets up temporal boundaries. On the other hand, yùu can be combined with lécW as well as with kamlan.

3. kamlan lécw Example 51 (d) náam kamlan róon kht̂n lécw 'The water's becoming hot already' seems to contradict the mutual exclusiveness of kamlan and lécw as discussed in point 2 above. The sentence is possible because the two markers do not refer to the same temporal unit. The marker kamlan operates on the phase introduced by khth 'go up', the marker lécw introduces an initial boundary and thus triggers an interpretation in terms of change of state.

4. When more than two aspect markers occur, cà? must be brought in. In our data, kamlan ca?, kamlan ca? __ yùu, and kamlan ca? _ yùu lécw seem all possible although kamlan ca? _ yùu without $l \varepsilon \varepsilon w$ is of doubtful acceptability. In all these combinations, we can generalize this phenomenon by the following rule:

When marker ca? is used, temporal boundaries either initial or terminative, must be inferred. If $l \varepsilon \varepsilon w$ as the boundary marker co-occurs, the imminent aspect 
as the beginning of the state of affairs or the terminative state of affairs depending on the verb class, is present. If $l \varepsilon \varepsilon \varepsilon w$ does not co-occur, the boundary is not focused, although implied. Thus, the imminent aspect is not present. We may say that with the combination of kamlan, yùu and lécw with $c a ?$ a preparation span of situation at the initial boundary or at the terminative boundary is introduced.

Following is the possible combination of cà? with the three aspectual markers to illustrate the mentioned points:

(55) a. khăw cà? kht̂n rzabin he-cà?-ascend-plane 'He will board the plane.'

b. khăw cà? kht̂n ruabin lécW he-cà?-ascend-plane-ASP

'He is about to board the plane.'

c. khăw kamlan cà? khân ruabin he-ASP-cà?-ascend-plane 'He is going to board the plane.'

d. khăw kamlan cà? kht̂n ruabin léeW he-cà?-ascend-plane-ASP He is about to enter the plane.

e. khăW cà? kht̂n rłabin yùu lécw he-ca?-ascend-plane-ASP-ASP 'He is about to enter the plan (he is closer to it than c.)' f. khăw kamlan cà? kht̂n ruabin yùu phoo dii he-ASP-ca? -ascend-plane-ASPthe very moment ' $\mathrm{He}$ is about to board the plane at the moment'

g. khăw kamlan cà? kht̂n ruabin léEW he-ASP-ca? -ascend-plane-ASP 'He is about to board the plane.'

h. khăw kamlan cà? kht̂nn ruabin yùu lécw he-ASP-ca? -ascend-plane-ASPASP

' $\mathrm{He}$ is just about to board the plane.'

From the comparison of (55f) and (55g) and the unacceptable sentence

* khăw cà? kht̂n rzabin yùu

(he- cà?-ascend-plane-yùu )

one can see that the grammaticality of the marker yùu depends on the presence of kamlay. Once kamlay and yùu are combined, the occurrence of these two markers together with lécW is possible. The following schema visualizes the

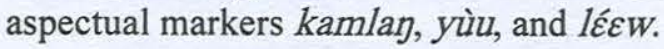




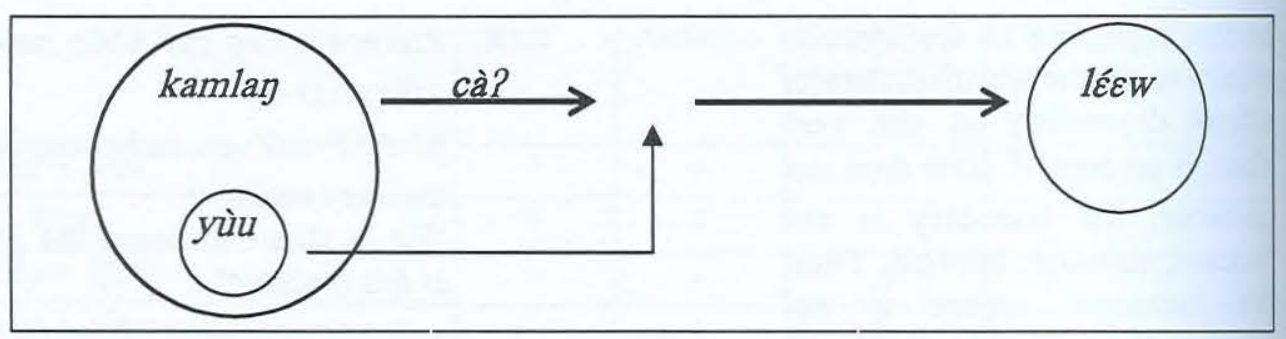

Figure 1. Schema of combinations of aspectual markers

5. It should be added that the sequence yùu lécw does not only have aspectual meaning. It also conveys pragmatic meaning against a wrong presupposition. The sentence 50 (c) yaay kin khâaw

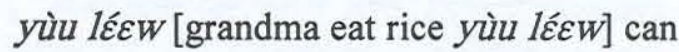
also be interpreted as a reaction against the wrong presupposition that grandmother did not eat. In everyday conversation, yùu lécw is a slang word with the meaning of 'of course, certainly'. If $l \varepsilon \varepsilon w$ highlights the initial boundary of the action state of affairs 'eat' in 50(c) a pragmatic reanalysis of this fact in terms of a confirmation that the action actually took place, seems plausible. In addition, this pragmatic interpretation is further reinforced by the continuative marker yùu. The following is an example of the use of yùu lécw as a slang word:

\section{khun cà? pay chianmày kàp} raw máy? - yùu lécw

you-FUT-go-Chiangmai-with-weQ-of course

'Are you going to Chiangmai with us? - Of course!'

\section{Conclusion}

In the present paper, we have tried to analyse aspect in Thai in terms of a selection-theory approach to see whether it can give a clearer explanation of aspect. We found the following:

1. An analysis of aspect in Thai can be clearer explained if an account for the temporal boundaries is taken particularly, the initial one when inceptive-stative state of affairs is to be explained. The four state of affairs as discussed in Vendler (1967) and Dowty (1979) do not seem to fully account for aspect marking in Thai.

2. Aspect markers do not only interact with lexically determined temporal boundaries. It is necessary to look at the temporal structure of the entire state of affairs with temporal strategies some of which we have dealt with, and with aspect markers, three of which we have studied in the article. It is seen that the temporal strategies which add information on the temporal structure of a state of affairs beyond the inherent properties of the verbs merit further studies.

3. In Thai, aspect markers can be used cumulatively. This is unusual in aspect languages with a binary aspect system of the perfective vs. imperfective type, in which aspect markers are complementary. 
If there is cumulative use of aspect markers, there is a hierarchy of dominance as explained in Figure 1 in section 5.2.5. Here, again a deeper research is needed especially with other aspect markers than kamlan, yùu lécw and cà? treated in this article.

4. To finish with our outlook, we would like to point out that it is typologically remarkable that a marker like cà? can establish a temporal boundary on its own which then interacts with other aspectual markers. The occurance of cà? with a boundary aspect marker lévW shows that in Thai, boundaries of a state of affairs are highly focussed. We do not know of any other language in which this is possible. But this needs a lot more research.

\section{References}

Bickel, Balthasar (1997). Aspectual Scope and the Difference between Logical and Semantic Representation. Lingua 102, 115-131.

Boonyapatipark, Tasanalai (1983). A Study of Aspect in Thai. Doctoral Dissertation, University of London.

Breu, Walter (1985). Handlungsgrenzen als Grundlage der Verbklassifikation. In Werner Lehfeldt (ed.), Slavistische Linguistik 1984, 9-34. München: Sagner.

Breu, Walter (2000). Zur Position des Slavischen in einer Typologie des Verbalaspekts (Form, Funktion, Ebenenhierarchie und Lexikalsche Interaktion). In Walter Breu (ed.), Probleme der Interaktion von Lexik and Aspekt (ILA), 21-54. Tübingen: Neimeyer

Comrie, Bernard (1976). Aspect. Cambridge: Cambridge University Press.
Dowty, David (1979). Word Meaning in Montague Grammar. Dordrecht: Reidel.

Johnson, Marion R. (1981). A Unified Temporal theory of Tense and Aspect. In Philip Tedeschi and Annie Zaenen, eds. In Tense and Aspect, 145-171. New York: Academic Press.

Koschmieder, Erwin (1928/1929). Studien zum Slacischen Verbalaspekt. In Zeitschrift für Vergleichende Sprachforschung 55, 208-304; 56, 78-105 (1934). Nauka o Aspektach Czasownika Polskiego Wzarysie. Próba Syntezy: Wilno.

Lyons, John (1977). Semantics. 2 Vol. Cambridge: Cambridge University Press.

Maslov, Ju. S. (1962). Voprosy glagol'nogo vida $v$ sovrmennom zarubez \& nom jazykoznanii. In Maslov, Ju. S. Voprosy glagol'nogo vida. Sbornik, 7-32. Moskau: Izd. inostrannoj literatury.

Noss, R. B. (1964). Thai Reference Grammar. Washington D. C.: Foreign Service Institute.

Panupong, Vichin (1970). Inter-sentence Relations in Modern Conversational Thai. Bangkok: The Siam Society.

Sasse, Hans-Jürgen (1991). Aspektheorie. In Hans-Jürgen Sasse (ed.), Aspektsysteme, 1-35. (Institut für Sprachwissenschaft, Universität $\mathrm{Zu}$ Köln, Arbeitspapier Nr. 14 [Neue Folge]). Köln: Universität zu Köln, Institut für Sprachwissenschaft.

Sasse, Hans-Jürgen (2002). Recent Activity in the Theory of Aspect: Accomplishments, Achievements, or just Non-progressive State?.

Journal of Linguistic Typology 6: 199-271.

Sookgasem, Prapa (1990). Morphology, Syntax, and Semantics of 
Auxiliaries in Thai. Doctoral Dissertation, the University of Arizona.

Warotamasikkhadit, Udom (1972). Thai

Syntax: An Outline. (Janua

Linguarum, Series Pratica, 68)

Berlin: Mouton:

Van Valin, R. D. Jr. \& Randy Lapolla

(1997). Syntax, Structure, Meaning and Function. Cambridge:

Cambridge University Press.

Vendler, Zeno (1967). Verbs and Time. In

Linguistics in Philosophy: Ithaca,

N.Y: Cornell University Press, 97-

121 